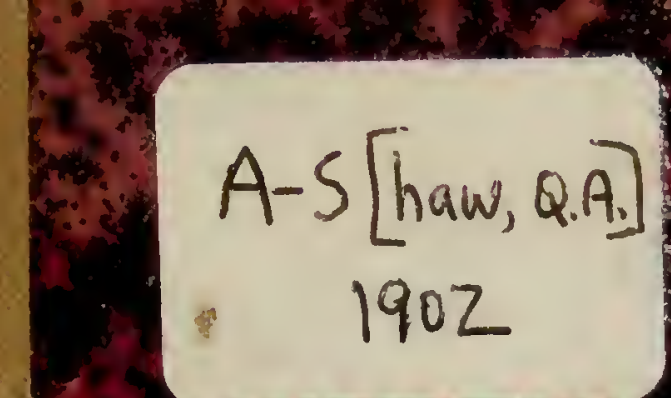

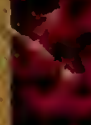

A-S $[$ haw, Q.A. $]$

Wis

$24 x=0$

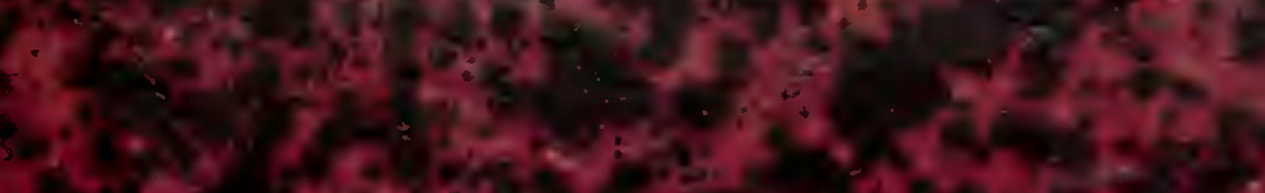

Tats

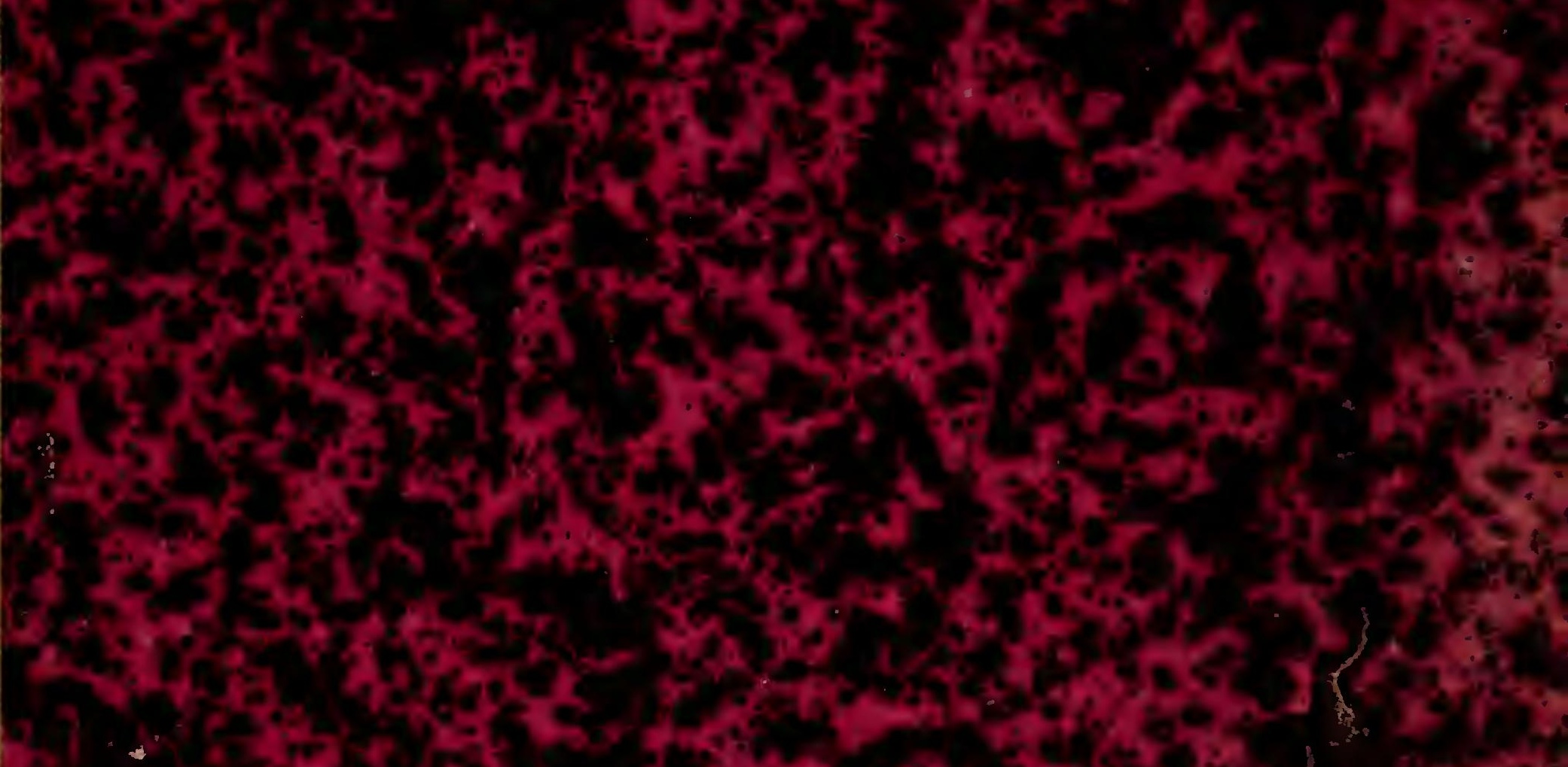

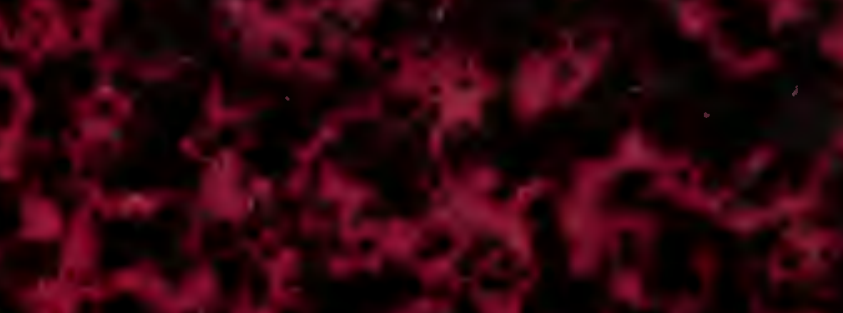

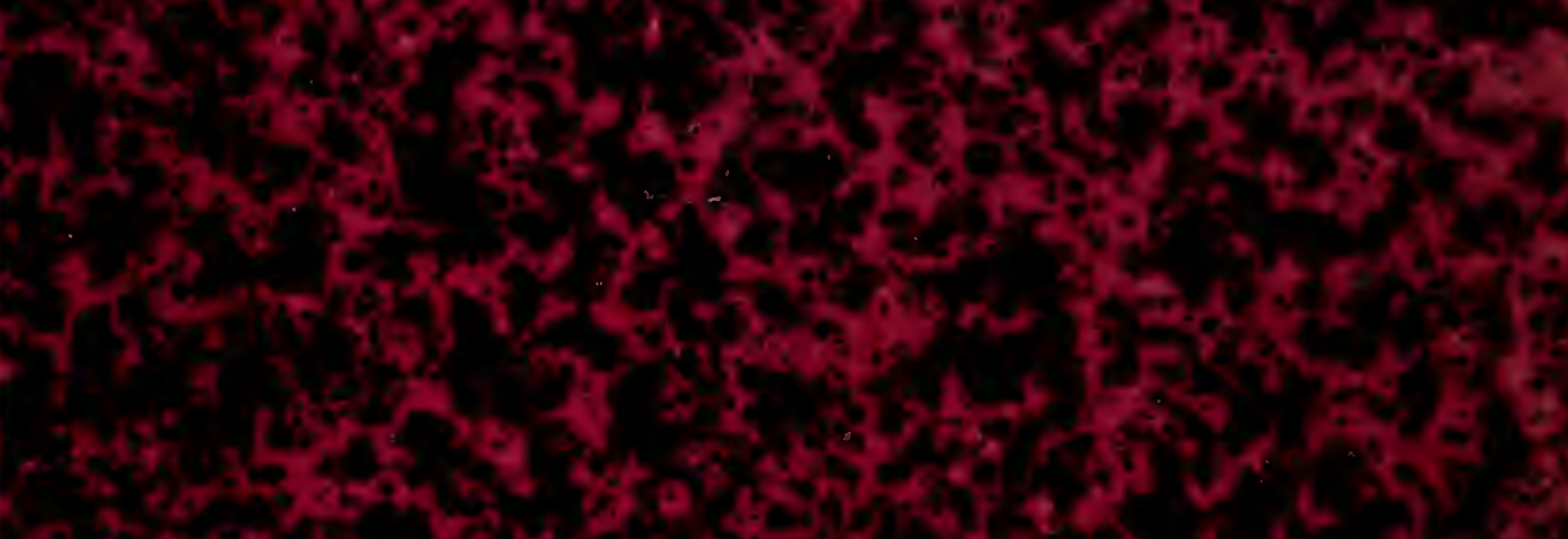

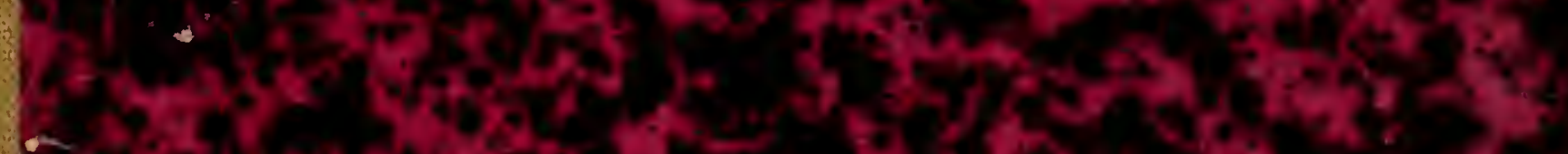

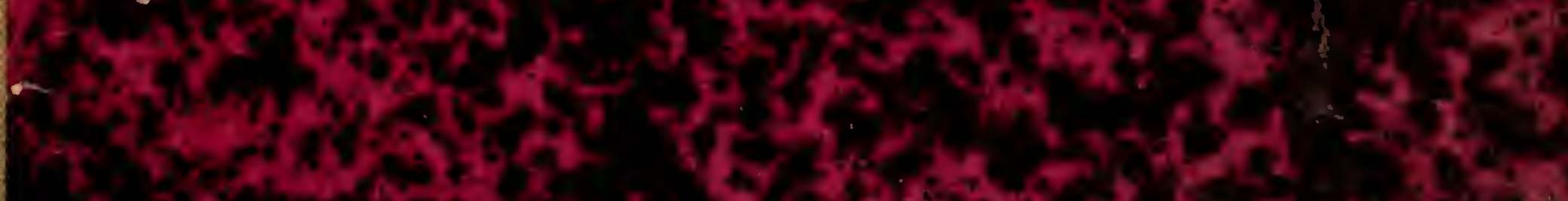

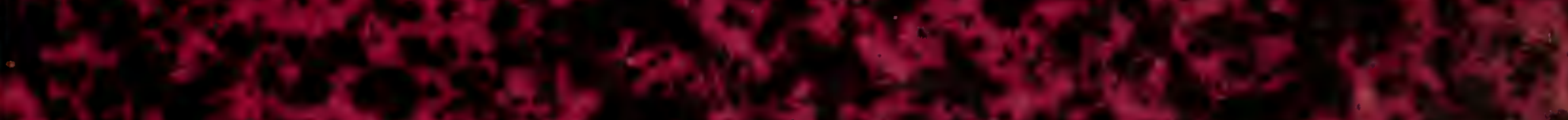

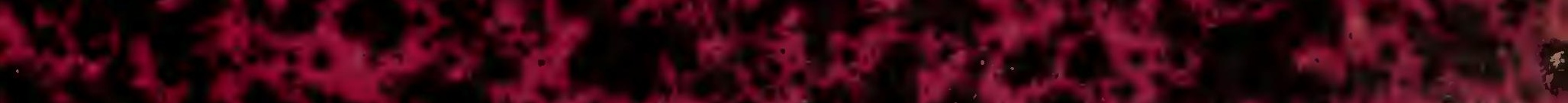

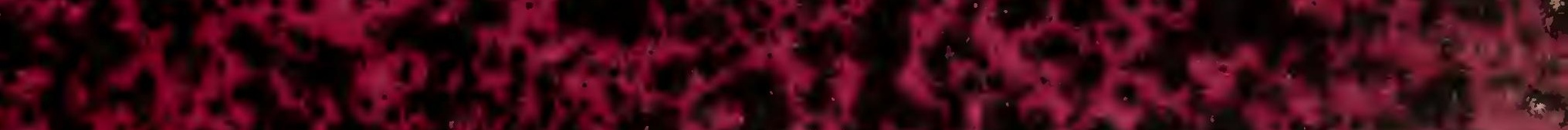

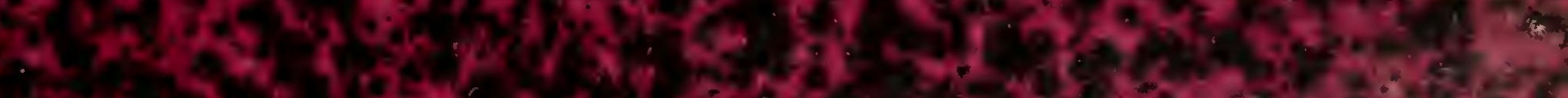

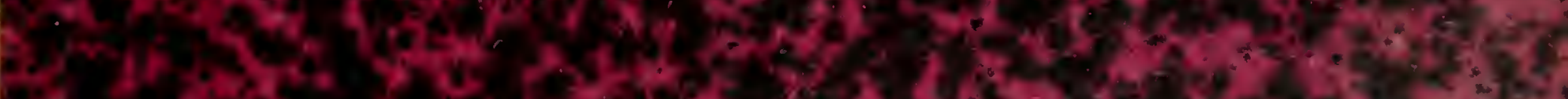

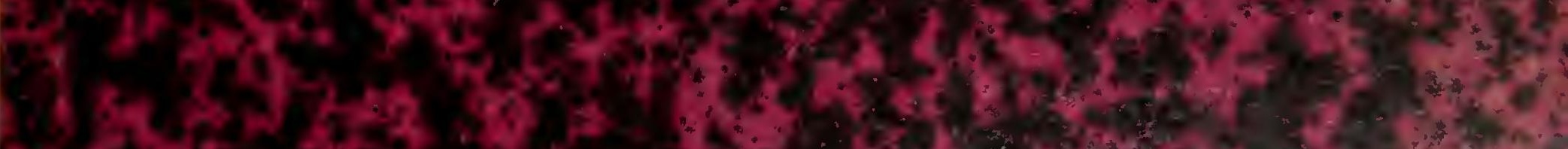

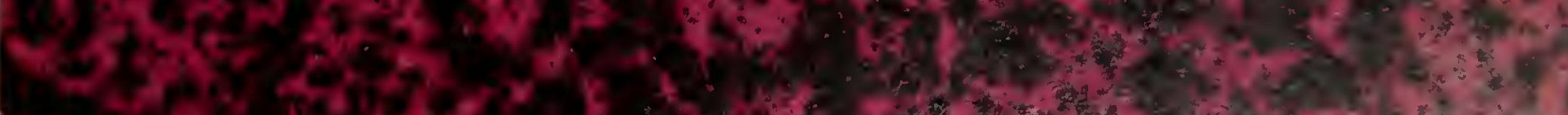
(F) 
HARVARD UNIVERSITY.

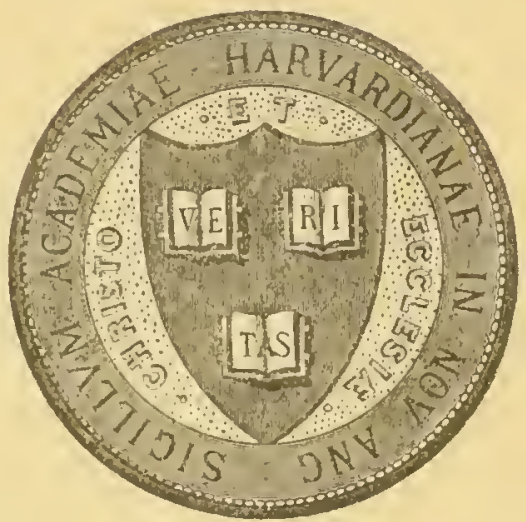

$\mathrm{LIBIA} \mathrm{A}$ I

OF TIIE

MUSEUM OF OOMPARATIVE ZOÖLOGY. 14,567

The Autho.

Atebrary 21,1902. 


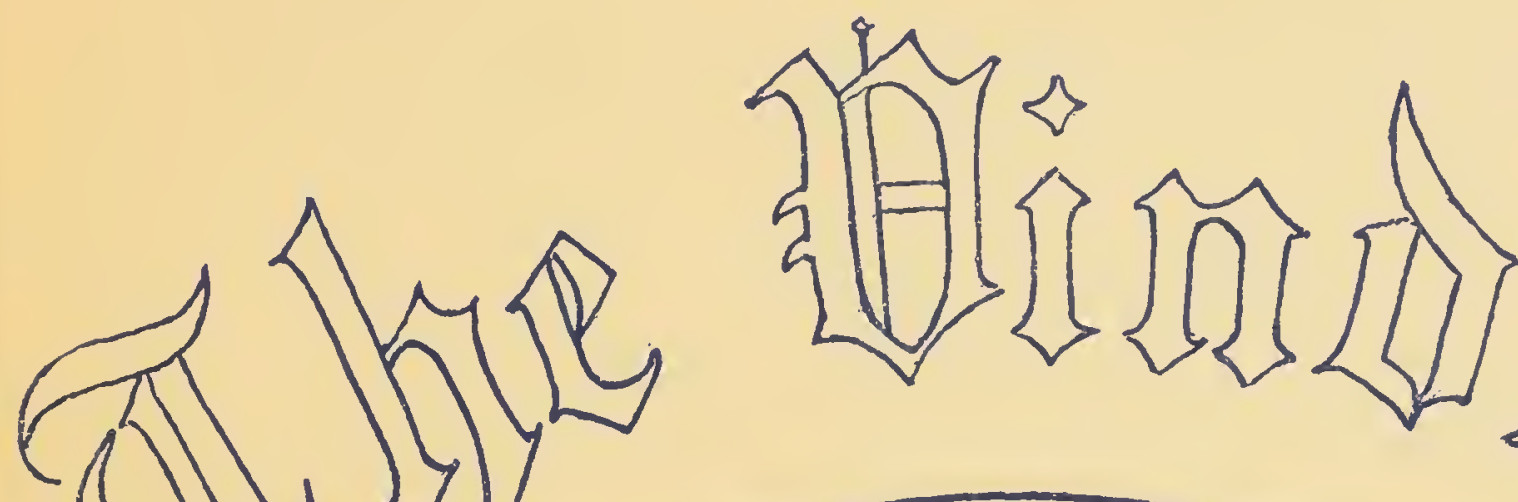

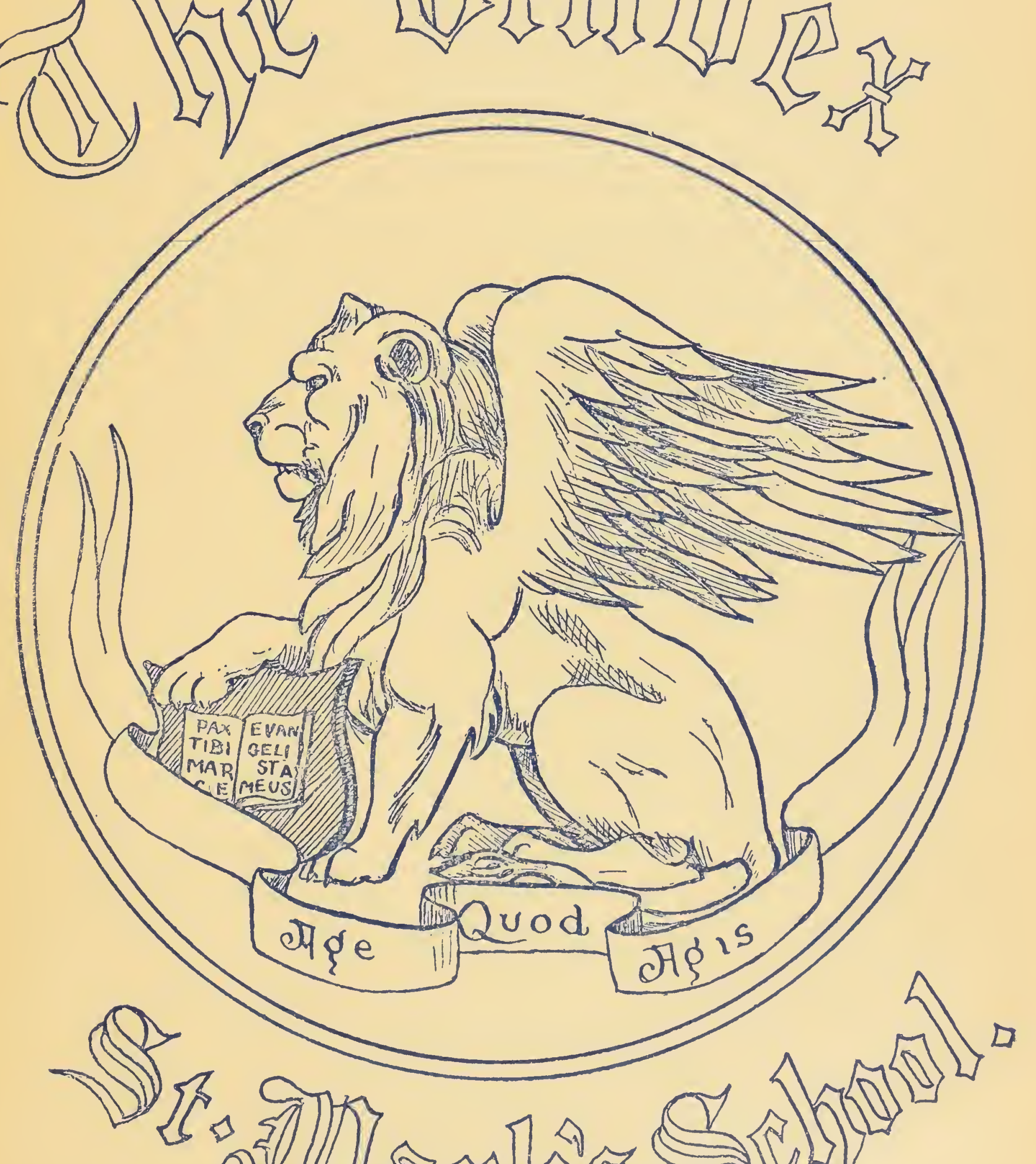

(2)

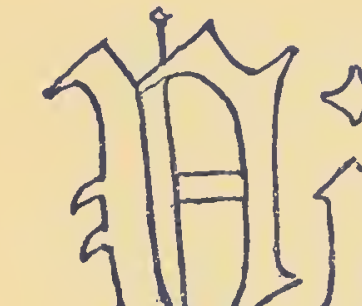

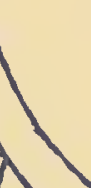





\section{THE VINDEX}

"AGE QUOD AGIS."

Vol. XXVI. No. 4.

Issued by Students of St. Mark's School.

JANUARY, I9OI

EDITORS.

Editor=in=Chief, LYMAN DELANO, '02

Associate Editors.

J. D. CAMERON BRADLEY, '02, P. G.

GEORGE H, BURNETT, '02, P. G.

NELLIS M. CROUSE, ' 02

WILLIAM WATSON, '02.

ALBERT L. CLARK, 03.

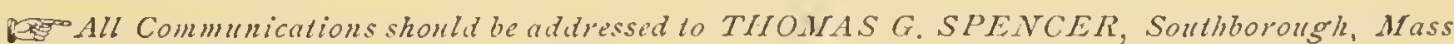

Business Manager. THOMAS G. SPENCER, 'o2

Ass't Business Manager. HARRISON TWEED, '03.
Editorials.

Dr. Morgan's Lecture.

Fives.

Hockey.

A Letter from Florence.

S. M. M. S.

The Gilbert Memorial.

The Birds of Southborough.

A Summer's Day.
CONTENTS.

The Christmas Plays.

The Sixth Form Speaking.

A Letter from Naples.

Revenge is Sweet.

Brevities and Levities.

Alumni Notes.

$\checkmark$ isitor's.

Exchanges.

Time Table.

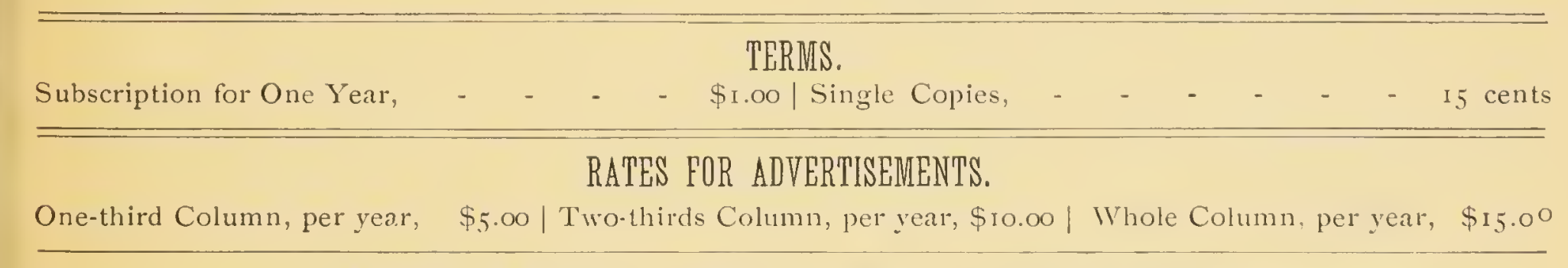

Entered in the Post-office at Sonthborough, Mass., as sciond-class mait matter.

By the time this number of the Vindex appears, the school will have settled down to work. The Christmas holidays passed with amazing rapidity, (and we hope that the reality was well up to our expectations), but most of us were ready to return to school when the three weeks were up. We have started on the Easter Tcrm, heretofore a term dreaded and looked upon as being dull and uninteresting. This seems to us to be looking on it from an crroneous standpoint. As a matter of fact there are nearly as many things to do in winter as at any other time. We have Fives, an excellent game, and one which secms to be growing in popularity daily. Out of doors we have skating, coasting, and hitching. The last sport does not seem to be indulged in this year as much as in former ones, yet the sleighing has been remarkably good, and for the benefit of those who have never tried hitching we would say it is a very enjoyable way of passing an afternoon. There has been very good coasting this tcrm on Fayville hill, where one gets a distance of over a quarter of a mile. The skating on the reservoir as yet has not been good As soon as we have good ice the snow spoils it, but a rink has been cleared now, and the 
hockey team expects to play several games with outside teams.

The gymnasium is always with us as a resort when out-of-door sports fail, and $\mathrm{Mr}$. Lathrop is ready every afternoon at three o'clock to coach the fellows individually. In considering what there is to do in the way of recreation we might mention again the oft repeated truth that this is essentially the term for hard study and conscientious work. We have found out from the Christmas examinations in what subjects we are lacking, and it should be our earnest desire to overcome these deficiencies, and prepare ourselves some for college, and others for the school examinations in the spring.

When we returned to school from the vacation we found that the new wing had progressed rapidly in our absence. The second floor was nearly completed and it was so far done that the fifth form were able to move into the new rooms on the $4^{\text {th }}$ of January. All the wood-work on this floor is stained a dark brown and the effect with the red or green walls, is admirable,

The lavatories are finished in marble, with stationary wash stands, one for every two fellows. The piping is nickel plated, and everything is almost luxurious. The third and fourth floors on which are the physics and chemistry laboratories, drafting, drawing and geography rooms, ought to be finished in a few weeks time. On the ground floor, the library will not be completed for several weeks, but the two new recitation rooms will b: rexdy for use within a few days.

The editors of the Vindex find it necessary to say something of the lack of support shown by the fourth and fifth forms. There seems to be a most unfortunate scarceness of literary effort. Next year's board of editors must be picked from the fourth and fifth forms, but judging by the interest and talent shown by them the outlook at the present time is not very bright. We hope that this matter will be taken seriously, and that it will not be neccssary for us to mention the subject again.

TuE Vindex takes great pleasure in welcoming Mr. Pricle, and wishes him the best of luck. As most of us already know, Mr. Pricle wrote the music for the Hasty Pudding play at Harvard last year; and it is with great gratification that we see him take up the training of the choir, and under his competent leadership expect to see them soon in a state of perfection.

\section{DR. MORGAN'S LECTURE.}

Dr. Morgan gave a stereopticon lecture on Pompeii to the School on Saturday, Dec. 7th. The lecture was one of the most interesting we have ever had, and Dr. Morgan's account of the terrible tide of ashes and lava that flowed over the city, was much added to by the pictures, which were exccllent, both in design and color. The lecturc began at eight o'clock and ended at nine.

Dr. Morgan commcuccl by showing the situation of Pompeii on a map and gave, at the same time, a short account of its history prior to the eruption of Vesuvius. The volcano had hitherto been regarded as extinct; its sides were covered with trees and vineyards, while at its foot were the towns of Herculancum and Pompeii, favorite resorts of Roman and Neapolitan society during the hot summcr. In $79 \mathrm{~A}$. D. the great eruption took place. For several days, great quanti- 
pause to give the serenader with a guilar at my window a chance to discorer his mistalic.) It requires a degree of resolution to circle the tower on one of the unrailed platforms, and the inclination of the roof is quite marked. The guardian of the tower refused to allow me to ascend alone, for the regulation demand; that no fewer than two may ascend at a tme. There was no one in sight, so I spent half an hour visiting the other places.

One of the loafers hanging about offered to make up the party and I was on the point of accepting his services when fortunately a Sicilian entered upon the scene and we two did the sights together. He delayed proceedings somen hat by writing his name on all the available space, but what with French and Italian we spent the time rery pleasantly together. In the baptistery we amusad ourselves by singing the chord of the octave and listening to the harmony that resulted from the very great prolongation of the echo from the concave ceiling and also by whispering along the wall.

The Campo Santo is a mortuary edifice, cloistered and quadrangular. Along the walls are p.tinted the most curious frescoes, among the very first of the renaissince paintings. Those that are sheltered from the direct lisht of the sun are exceedingly well preserred. Death and hair-breadth escapes from the fury of the lemon form the main theme of the series. All the monks are easily saved although they die ghastly deaths, while with other people it's a close call all reund.

The new Campo Santo is simply a Philistine marble shop. Worse. Formless old women and men in baggy trowsers have themselves represented in marble; with embroidered handkierchief at their eyes and dropping conspicuous tears at the tombs of the departed-copies from real life. This must be the real age of Italian art.

The Sicilian had an animated discussion with the coachman about the fare and then all three of us went each his own way in peace and sobriety.

I am still rubbing my eyes to banish, for the salie of a little repose, the image of the polished mable mosalics within and without the Cathedial at Pisi. That picture of S. Mavia of Florence, which hangs in the corriclor does fairly well for a photograph, but the reality fairly staggers one. I am earnestly hoping for fair weather to enable me to malie the round of the galleries.

The mountains of Carlara merit a remark. When I passed then the Western sun was shining brightly on their summits and gave some curicus effects. They looked like huge schated piles of lime slightly slisied, quite different from anything of the kind I lave ever seen.

Yours as ever,

WILLIAM D. REES.

\section{S. M. M. S.}

The 33rd meeting of the St. Mark's Missionary Society was held in Mr. Thayer's study, Sunday evening, Dec. Ist. President Bradley called the meeting to order at 7.30 . The minutes of the previous meeting, together with the treasurer's report, were then read and accepted. Hutchinson then moved that $\$ 50.00$ be given to $\mathrm{Mr}$. Cambridge in partial payment of the $\$ 250.00$ promised him. It was seconded and carried. Mr.
Thayer read a letter from Mr. Wood about the college of St. John's in Shanghai, China; he then spoke a few words about the college and missionary work in China. The meeting adjourned at 8.00 .

The 34th meeting of St. Mark's Missionary sociaty was held in Mr. Thayer's study on Sunday evening, Jan. I2, at 7.30. President Bradley called the mecting to orcler at $7 \cdot 30$. The minutes of the previous meeting, together 
with the treasurer's report, were read and accepted. Fay R., and Fay P., were nominated tor secretary of the Society, as this office was vacant, on account of Willard's resignation. Fay $\mathrm{R}$. was elected. $\mathrm{Mr}$. Thayer then read a letter from Mr. Thomas
Gray of Hampton Institute. Mr. Carter of the Harvard Christian Association gave an interesting talk about missionary work. The meeting adjourned at 8.00.

RODMAN FAY.

\section{THE GILBERT MEMORIAL.}

On Sunday, January twelfth, a window was unveiled in the chapel to the memory of Grenville Brown Gilbert, who died at the school last March.

The memorial was executed by Tiffany \& Co., of New York, in accordance with suggestions from Mr. Thayer and a committee of the school. The clesign is a close copy of Watt's famous picture of Sir Galahad; a knight in white armour standing by his horse's head, the background of rich green foliage. The white figure is in strong relief at any hour of the day, and with the full sunlight upon it the whole effect of the window is beautlful.

It is hard to conceive of anything else which would be equally suitable and satisfactory as a permanent token of the affection of the boys who were members of the school last year when one greatly loved was taken from us by death.

The new window is placed on the west side of the chapel, and the window given by the Alumni to the memory of Mr. Peck has been moved to the east side, where the stronger light brings out a wealth of color never seen before.

\section{6,504}

"It is worth while to make a voyage up this stream, *** only to see how much country there is in the rear of us ; great hills, and a hundred brooks, and farm houses, and barns, and haystacks, *** and men cverywhere *** that is Southborough men, *** Look at their fields, and imagine what they might write, if ever they should put pen to paper." - Thoreau.

This list prepared by Quincy A. Shaw, 'OA, under my direction and supervision, is compiled from notes made by the boys of St. Mark's School during the past few ycars, especially from those made on ficld cxcursions conducted by me in the spring and autumn of 19or. The records have been carefully revised by Shaw, and the list though comparativcly small is accurate and reliable, and offers a good basis for future work.

Many of the boys have entered into the study with commenrlable interest. Abbot E.
'Or, Stearns '05, Biddle 'O4, Husband 'O4, Burke 'O4, Eames '05, IVood 'O4, and Chapin J. 'o6, should be especially mentioned as well as Shaw to whom the School is indebted for this list.

Onithology is yearly becoming a more generally recognized science, and is entering prominently into the natural science department of schools. The field excursions are not only valuable in developing the power of observation, training of eye and ear to appreciate the wonders of the natural world, and the broadening influence gained by a close relationship to nature, but are beneficial in that they give healthy, moderate exercise out of cloors.

\section{Reginald Heber Howe, Junior.}

A list of the birds obserred within a radius of five miles of St. Marli's School, Southborough, Massachusetts: 
Ruffed Grouse (Bonaser mulullus) Common permanent resident.

Bob-white (Colnins aimsiniams) Common permanent resident.

Spotted Sandpiper (Actitis macularia) Rare summer resident.

Great Blue Heron (Anded horodias) Common migrant Apr. Foth to May 6:h.

Canada Goose (Bronta canadensis) Rare migrant April 6th.

Blaek-erowned Heron ( $N^{\top} y^{\prime}$ ctcorax nycticorax uracins) Uncommon resident Apr. 27th to

Marsh Hawk (Circus hudsonins) Common summer resident, Apr. 25th to-

Cooper's Hawk (Accipiter cooperii) Unecmmon summer resident, May and to-

Red-tailed Hawk (Butco borcalis) Uneommon permanent resident.

Red-shouldered Hawk (Butco lincatus) Uneommon permanent resident.

Pigeon Hawk (Folco columbains) Uucommon spring and autumn migrant, June soth.

Sparrow Hawk (Firleo sparanins) Common summer resident.

Sereeeh Owl (Mcrascops asio) Common permanent resident.

Balted Kingfisher (Corylc alcyon) Common summer resident.

Chimney Swift (Chactura polagica) Abundant summer resirlent, May $4^{\text {th }}$ to-

Ruby throated Hummingbird (Trochilns colubns) Common summer resident, May I 2 th to-

Yellow-billed Cuekoo (Coccysus amaricamis) Common summer resiclent, May 28 th to

Black billed Cuekoo (Cocouns erythrophthalmus) Common summer resident, May $22 n d$ to-

Northern Flicker (Colaptes anratus lutens) Common permanent resident.

Hairy Woodpeeker (Dryobates aillosis) Uncommon summer resident, May ith to

Northern Downy Woodpecker (D)ryobates pubescons mediams) Common permanent resident.
L cast Flyeatcher (Empidonax minimus) Common summer resident, May 23rd to-

Wood Pewee (Horisopus airens) Common summer resident, May 26 to-

Phoebe (Sayornis plocbe) Common summer resident, Apr. ?7th to-

Kingbird (Tyrommus tyrommus) A bundant summer resident, Apr. 29th to

Bank Sivallow (Clivicola riparia) Common summer resident, May 2d to

White-bellied Swallow (Tachycineta bicolon) Abundant summer resident, May $9^{\text {th }}$ to

Barn Swallow (Himudo crythrogerstre) Common summer resident, April 2oth to

Eave Swallow (Petrochclidon punfions) Uncommon migrant, April zoth to

Cedar Waxwing (Ampclis cedromm) Uncommon permanent resident.

Yellow throated Vireo (Tirco farifrons) Common summer resident, May i $3^{\text {th }}$ to

Warbing Vireo (Tireo gritans) Common summer resident, May $24^{\text {th }}$

Red-eyed Virco (Virco oliarcens) Abundant summer resident, May gth to

Ameriean Crow (Coriss amoricanns) Common permanent resident.

Blue Jay (Cyanocitta cristata) Common permanent resident.

Chiekadee (Parus atricapillus) Abundant permanent resident.

White-breasted Nuthatch (Sitta carolinonsis) Common spring and autumn migrant and winter resident.

Brown Crecper (Certhir familiaris americanc) Common spring and autumn unigrant and winter resident.

Brown Thrasher (Horporhyonchns mifus) Con. mon summer resident, Nay Sth to

Catbird (Gelcoscoptes carolinuris) Common summer resident, May Gth to

Bluebird (Siclia sialis) Common summer resident, May 24 th to

American Robin (Mcmla migratoria) Abundant summer resident, March 23d to 
Bicknell's Thrush (Hylocichlar aliciac bicknclli) Rare, spring and autumn migrant.

Wilson's Thrush (Hylocichlar) Common summer resident.

Wood Thrush (Hylocichla mustclina) Common summer resident, May gth to

Golden-crowned Kinglet (Regulus satrapa) Common spring and autumn migrant and winter resident.

Redstart (Stophagarnticilla) Abundant summer resident, May i 4 th to

Canadian Warbler (Milsonia candensis) Common spring and autumn migrant, May igth

Maryland Yellowthroat (Geothlypsis trichas brachidactyla) Abundant summer resident, May I 3 th to

Connecticut Warbler (Gcothlypsis agilis) Common autumn migrant.

Vater Thrusin (Suirus norcboraccnsis) Uncommon spring and autumn migrant, May $24^{\text {th }}$

Oven-bird (Siums aurocapillus) Common summer resident, April 27 th to

Yellow Palm IVarbler (Dcndrocea palmamm leypochrysea) Common spring migrant, May I Sth

Pine-creeping Warbler (Doutroced aigorsii) Uncommon summer resident, May 5 th to

Black-throated Green Warbler (I)cudrocea fircus) Common summer resident, May 13 th to

Black-poll Warbler (I)cudroced stricta) Uncommon autumn migrant.

Bay-breasted Warbler (Dondrocic sirens) Rarespring and autum migrant May 24 th Chestnut-sicled Varbler (I)cudrocid finsilaranica) Common summer resident, Maly I ith to

Yellow-rumped Warbler (1) chedroced cononate) Common spring and autumn migrant, May 6ith

Black-throated Blue Warbler (Dindroced carulcusis) Uncommon spring and autumn migrant, May i 3 th

Yellow Warbler (Dendrocer acstica) Abundant summer resident, May Sth to
Parula Warbler (Compsothlypsis amoricand usncac) Common summer resident, May 5 th Nashville Warbler (IIelminthrophila mbricapille) Uncommon summer resident, May' gth to

Black and White Warbler (Mnio varia) Common summer resident, May I I th to Scarlet Tanager ( Piranga ludoriciaud) Com. mon summer resident, May igth to

Bronzed Grackle (Quisculus quisculd acncus) Common summer resident, April i 5 th to

Rusty Grackle (Scolccoplaggus carolinus) Common spring and autumn migrant, April 6th

Baltimore Oriole (Pictcrus galbula) Common summer resident, May i ith to

Meadow Lark (Stumclla magna) Common summer resident, April i6th to

Red-winged Blackbird (Agclacns pliocuiccus) Abundant summer resident, April isth to

Cowbird (Molothous ater) Common summer resident, April 24th to

Bobolink (Dolichorny'x orysivorns) Abundant summer resiclent, May gth to

Indigo Bird (Passerina cynca) Common summer resident, May 2 Ist to-

Rose-breasted Grosbeak (Zamclodia ludorician:y) Common summer resident, May gîh to

Towhee (Pifilo cuthrophthalus) Common summer resident, May ist to

Fox Sparrow (Passcidla iliaca) Common spring and autumn migrant, April $2 \mathrm{~d}$.

Swamp Sparrow (Melospiza georiana) Uncommon summer resident, April gth to

Song Sparrow (Mclospiàn melodic) Abundant summer resiclent, March 24 th to

Field Sparrow (Spizillic pusilla) Common summer resident, April I Sth to

Chipping Sparrow (Spinclla socierlis) Abundant summer resident, April 2 rst to

White-throated Sparrow (Zonotrichia albicol(is) Common spring and autumn migrant, April 5th

iVhite-crowned Sparrow (Zonotrichia lou cophry's) One instance May I 6 th. 
Henslow's Sparrow (Ammodianns honslowir) One instance May gth.

Savannah Sparrow (Passerculus sandwichensis sarenua) Common spring and autumn migrant, May 5th.

Vesper Sparrow (Pooccetes gramincus) Abundant summer resideni, April $S$ th to

Snow Bunting (Plectrophemar niralis) Uncommon winter visitant.
American Goldfinch (Astragalimmes tristis) Common permanent resident.

Redpoll (Acanthms linaria) Uncommon winter visitant, Feb. 4th.

White-ivinged Crossbill (Loria lencoptera) Rare winter visitant.

Purple Finch (Carpodacns perpurens) Rare summer resident, May 2 d to

\section{A SUMMER'S DAY.}

There was no doubt about it, Jimmie Hardruff was in love with Louisc Michael. The fact was plain to Jimmie's friends, and some of them were so sure he was well received that they had bet the engagement would be officially announced within two months. Jimmie was a tall athletic young man of twenty four, the proud possessor of a magnificent set of muscles which received vigorous exercise every clay for Jimmie was a "lifter" employed by Bootman \& Co. Each night it was a source of enjoyment for him to go down to the gymnasium and show off these muscles by ingenious tests of strength. Louise, or Miss Michacl as Jimmie calied her, was employed as a waitress in a down town restaurant, where her good looks had won her a great many admirers.

One evening towards the last of Junc, Jimmie asked Miss Michael to spend the 4 th of July at the Salem IVillows, and there sece the various sights. Louise accepted with pleasure and ten o'clock found them on board the steamer- Fifteen minutes later a bell clanged somewhere in the bowels of the ship, the old-fashioned paddle wheels slowly revolved and the Beverly started out on her daily journey to Salem Willows. During the confusion, Jimmie had seized the opportunity to draw two chairs to the side of tlac vessel underneath a great iron anchor which shielded them somewhat from the wind. After the Brewsters were safely passed, Jimmie's heart began to throb and his cheeks to flush painfully; at last he managed to break off Miss Michael's endless flow of talk with this very abrupt speech,

"Say Louise, I love you and I want you to marry me. Is't a go?"

Miss Michacl turned her gaze from the receding light house to Jimmie's red, embarassed face and after staring at him thoughtfully for a moment she said,

“No, Jimmie, I'm 'fraid I can't. Yer pay ain't large enough to support us both, for of course you'd want me to give up my work."

This answer completed Jimmie's discomfiture and after glancing at Miss Michael's determincl face he looked away again at a waite sea gull wheeling and diving in the distance. An embarassed silence ensued for some time which was only broken by the buerly's arriving at her pier at the Willows. In a few minutes all the passengers had disemburked and as Jimmic and Louise crossed the gang plank, Miss Michael saicl :

"IVell, Mr. Hardruff, as you can't be more agrecable, I'm going to leave you until you come to a more sociable state of mind. l'raps I won't see yer till we go back on the steamer."

With these words she left him, and calling to a girl friend on the other side of the strect she crossed over and went into an ice cream parlor with her new companion. Jimmie, thus cruelly deserted, walked up the street with despair gnawing in his heart; it was his first offence and he had been heavily 
punished. How could he make Louise change her mind? She certainly saicl he dicln't have money enough ; and if he managed to get a rise would she marry him? Why, of course. Just then a little voice whispered, perhaps you are not the only one in love with her. Possibly her heart may be given to that little Jennings. Jimmie smiled as he thought of Jennings ; a little two-for-a-cent, five-foot sawed-off. Just about one mouthful. No it couldn" 'r:nnings.

Jimn ., wrapped in his thoughts, had walked quite a way up the street, and at last his oblivion was pierced by the hoarse voice shouting out the following information to the passers-by.

'Step up, ladies an' gents, step up and see Nazro, the Trrrible Turk, champion wrestler of the world.

nds hire ready to challenge all comers for a purse of \$ I,000. If the loser succeeds in winning one round in three he shall have one-fourth of the gate receipts. Step up, ladies and gents, only ten cents to see Nazro, etc."

Thinking to pass away the time Jimmie paid ten cents and walked into the tent. Inside there were some chairs on a sawdust floor and a platform, covered with matresses, on which sat the redoutable Nazro. He was a man, swarthy in complexion, six feet tall, with broad shoulders and a tremendously deep chest, clad in tights, every movement showing his bulging, knotted muscles. Idly Jimmie fell to comparing himself with the wrestler. Jimmie was slightly taller, his shoulders not so broad, though his chest was nearly as deep ; there was, however, a wrestless activity about him that was not apparent in Nazro, who seemed to be like an immovable pillar of stone. All of a surlden this thought flashed through Jimmie's brain. "Why shouldn't I accept this challenge? I've wrestled a good deal in Boston, and the experience would be useful to me. I don't care much about livin' now, anyway, and a lickin' would do me a world of good. And then? if I should win, the money would - for Louise - I never thought of it. Yes I will try it."

With this intention in view he strolled up to the "barker," and saicl:

"Hey, Boss, I'm willin' 'ter take up that challenqe but I've got ter fight terday. Can yer fix it?"

The "barker" was silent for a moment eyed Jimmie thoughtfully for a moment and saicl at length:

"I tell yer. I've got ter speak to Nazro about it. If he says 'all right', all right it'll be."

Then he walked into the tent and after a few minutes conference he came out again, and nodding to Jimmie, shouted to the crowd.

"The challenge has been taken up by a celebrated Boston wrestler and the contest will take place here at three. Admission $75 \mathrm{c} . "$

Then the "barker" turned to Jimmie and told him to be there at half past two sharp and to be sure to bring clothes to wrestle in.

At three o'clock the tent was jammed to suffocation with an aggregation of sports, toughs, and a sprinkling of women. Suclclenly a curtain back of the platform was pulled aside, and Nazro and Jimmie appeared clad in wrappers. The barker who acted as referee and umpire stepped to the front of the platform and said:

"Gentlemen, we are gathered here to see two of the most famous wrestlers in the world, (here Jimmie and Nazro bowed grace. fully) meet in terrible struggle. There are to be two rounds, each round lasting until one of the two is thrown; in case of each man's winning a round there will be a third to decide the contest. Gentlemen, Nazro, the terrible Turk, and Mr. Hardruff."

At this Nazro and Jimmie, throwing off their wrappers, stood before the audience clothed in tights and advanced to the middle of the platform and shook hands. Then they backed away from each other and began to circle around, bending forward and 


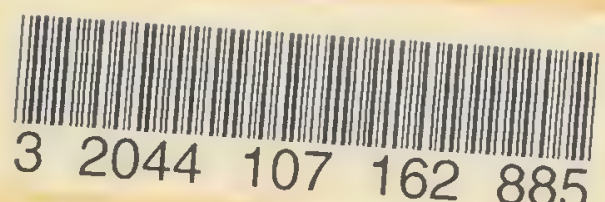




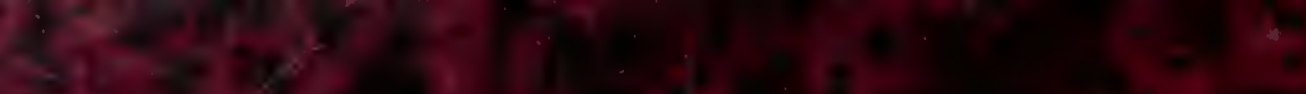

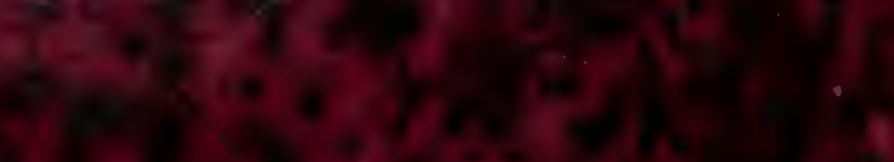

